\title{
Landscape and pesticide effects on honey bees: forager survival and expression of acetylcholinesterase and brain oxidative genes
}

\author{
Mohamed Alburaki ${ }^{1}$, Sandra J. Steckel ${ }^{1}$, Deniz Chen $^{2}$, Erin McDermott ${ }^{2}$, \\ Milagra Weiss ${ }^{3}$, John A. Skinner ${ }^{4}$, Heather Kelly ${ }^{1}$, Gus Lorenz ${ }^{5}$, David R. TARPY ${ }^{2}$, \\ William G. MeIKLE ${ }^{3}$, John AdAmCZYK ${ }^{6}$, Scott D. SteWART ${ }^{1}$ \\ ${ }^{1}$ Entomology and Plant Pathology Department, West Tennessee Research and Education Center, The University of \\ Tennessee, 605 Airways Blvd, Jackson, TN 38301, USA \\ ${ }^{2}$ Department of Entomology and Plant Pathology, North Carolina State University, Raleigh, NC 27695, USA \\ ${ }^{3}$ USDA-ARS Carl Hayden Bee Research Center, Tucson, AZ 85719, USA \\ ${ }^{4}$ Entomology and Plant Pathology Department, The University of Tennessee, Knoxville, TN 37996, USA \\ ${ }^{5}$ Lonoke Research and Extension Center, University of Arkansas, Lonoke, AR 72086, USA \\ ${ }^{6}$ USDA-ARS - Thad Cochran Southern Horticultural Laboratory, Poplarville, MS 39470, USA
}

Received 21 April 2016 - Revised 10 January 2017 - Accepted 18 January 2017

\begin{abstract}
The aim of the present work was to assess the effects of landscape and pesticides on honey bee survival and physiological stress. Integrated use of acetylcholinesterase and detoxification enzymes was tested on honey bee brains for detecting possible exposure to pesticides. Foragers were tracked in agricultural and non-agricultural landscapes in West Tennessee (USA) and then recovered for molecular and chemical analyses. In addition, four honey bee cohorts were fed imidacloprid in the laboratory ad libitum for several weeks and were analyzed by RTqPCR for gene expression. Pesticides were identified at different concentrations in both crop flowers and recovered foragers. No significant differences in foragers' mortality were found among locations. Acetylcholinesterase and detoxification genes showed no response to exposure to pesticides except for GstS3 and GstS4. Our results suggest that none of the studied genes make suitable biomarkers for honey bee exposed to pesticides.
\end{abstract}

\section{honey bee foragers / agricultural landscape / crops / gene expression}

\section{INTRODUCTION}

The honey bee (Apis mellifera) is one of the most economically important insects for humans. Besides providing six different products (honey, pollen, wax, royal jelly, venom, and propolis), the honey bee plays a significant role in plant pollination, including various domestic crops (Aizen et al. 2009). The well-publicized mortality of honey bee populations recorded in the last decade

Corresponding author: M. Alburaki, malburak@utk.edu Manuscript editor: Bernd Grünewald
(Bacandritsos et al. 2010; Johnson et al. 2010) predicted a looming pollination crisis that may threaten worldwide food security (Withgott 1999; Kremen and Ricketts 2000). This is especially true since the value of crops pollinated by bees was estimated at US\$14.6 billion in the USA alone in 2000 (Morse and Calderone 2000).

Despite the ongoing debates regarding the causes of honey bee decline around the world, a majority of the scientific community considers this decline to be a multifactorial phenomenon (VanEngelsdorp et al. 2010; Wu et al. 2012). This means that no single factor - such as pathogens and parasites (Fries 2010; Dainat et al. 2012), insufficient experience in honey bee hive management, or excessive use of pesticides 
(Johnson et al. 2010; Van der Sluijs et al. 2013) - is individually causing honey bee decline or mortality, but the contribution of various factors acting together are responsible.

Some widely used pesticides, such as neonicotinoids, are known to be extremely toxic for bees (Williamson et al. 2014; Chakrabarti et al. 2015) and can, even at sublethal doses, significantly decrease honey bee performance such as brood production, weight gain, disease resistance, and trigger disorders in colony dynamics and labor partition (Mackenzie and Winston 1989). These insecticides are valuable for pest control in agriculture, increasing the crop production and providing a worldwide food security (Potts et al. 2010; Godfray et al. 2014). Pesticide residues at various concentrations were identified in honey bee products and hives (Lambert et al. 2013).

The equivocal results obtained from studies on honey bee in-field pesticide toxicity and exposure, tolerated level of exposure, and effect on honey bee health (Blacquière et al. 2012; Henry et al. 2015) have raised new questions and debates. It is believed that in order to ameliorate these problems and find sustainable solutions, closer collaborations and information exchange between pesticides companies, the scientific community, agriculturists, and beekeepers is strongly needed.

In this study, we are particularly interested in testing whether the use of agricultural pesticides has in-field impact on forager bees' activity and survival. Forager bees are more susceptible to infield exposure to pesticides during their foraging flights compared to in-hive nurse bees. It has been shown that forager behavior, orientation, communication dances, and return flights are all highly affected by sublethal insecticide doses (Vandame et al. 1995; Williamson et al. 2014). Neonicotinoids, in particular, can impair the olfactory memory and learning capacity of honey bees (Decourtye et al. 2005; Aliouane et al. 2009; Williamson and Wright 2013; Williamson et al. 2014) and alter the homing behavior of forager bees (Fischer et al. 2014). Besides tracking in-field forager bee mortality in our current study, we have tested both recovered foragers from the field and bees that were fed imidacloprid in the lab to determine the variability in the activity of five genes (AChE, CAT, GstD1, GstS3, and GstS4) as potential biomarkers of exposure to oxidative stressors (Lionetto et al. 2003; Durou et al. 2007). Some of these genes are part of the known antioxidant gene families in honey bees (Corona and Robinson 2006), while others are known to be linked to pesticide sublethal toxicity in both honey bees (Boily et al. 2013; Alburaki et al. 2015) and bumble bees (Samson-Robert et al. 2015).

\section{MATERIALS AND METHODS}

\subsection{Honey bee colonies}

This experiment was conducted on four honey bee colonies. In May 2015, four new colony divisions, equal in size, were made from existing, overwintered colonies of standard stock. Four sister Carniolan (Apis mellifera carnica) queens, artificially inseminated, were purchased from a commercial queen producer at the same period and introduced into these four new colonies. The new queens and divisions were housed in new ten-frame Langstroth hives, and a board $(1.5 \times 1.5 \mathrm{~m})$ was placed in front of each hive to help observe and collect any bee mortality at the front entrance. When an unusual number of dead bees ( $\sim 50$ or more) were observed on those boards, dead bees were collected and sent for pesticide residue analysis as described below.

\subsection{Location and landscape}

In order to assess forager survival and/or stress related to probable pesticide in-field exposure, four different landscape locations were carefully chosen. First, candidate locations were selected, and geographical information system (GIS) studies were conducted on a $2.5-\mathrm{km}$ radius from each candidate location. The GIS analysis was conducted in order to assess the agricultural (AG) areas or crop fields available for honey bees within a typical foraging distance for honey bees (Seeley 2010). The GIS study was performed using Esri ArcGIS® software (Redlands, CA).

\subsection{Marked and recovered bees}

One beehive was assigned to provide a source capped brood in our studies. This assigned hive was not part of this study and served only as a source for capped brood frames. One day prior to the date of introducing bees into our experimental hives, three capped worker brood frames, which were close to worker eclosion, were kept for $24 \mathrm{~h}$ in an incubator at $35^{\circ} \mathrm{C}$ 
and $53 \%$ relative humidity. One-day-old bees that hatched the next day were randomly divided into groups of 50-60 bees, and they were collectively marked by a dot on their dorsal tergite using a collective marking box designed after (Alburaki 1990).

Three hundred marked bees were introduced in each of the four experimental hives on four different dates (Table I). In addition, a control set of 300 1-day-old marked bees were randomly selected on each marking date and stored at $-80{ }^{\circ} \mathrm{C}$. Introduced bees were left in hives for 20-22 days, except for the first date (42 days). Marked bees were then manually recovered from the hives and killed on dry ice and stored at $-80{ }^{\circ} \mathrm{C}$ (Table I). Heads of both recovered bees (mostly foragers) and the control bees were subsequently dissected and separated for subsequent gene expression analyses, while the rest of their bodies were sent for pesticide residue analysis.

\subsection{Honey bee samples fed in the lab}

One-day-old bees were used in three different treatment groups (B, C, D) and a control group (A) as described in Table II. Capped brood frames were taken from three hives and placed in an incubator at $35^{\circ} \mathrm{C}$ and $53 \% \mathrm{RH}$, and monitored for $48 \mathrm{~h}$. During that time, emerging bees were placed in Plexiglas ${ }^{\circledR}$ cages $(100$ bees/cage) and fed ad libitum with water, a protein patty, and sugar syrup. The sugar syrup provided for cages B, $\mathrm{C}$, and D contained, respectively, different imidacloprid concentrations of 5,20 , and $100 \mathrm{ng} / \mathrm{g}$. Imidacloprid was chosen as being the largest used insecticide in the world (Jeschke et al. 2011; Stoner and Eitzer 2012). Honey bees of the control group (A) were fed with regular sugar syrup that contained no imidacloprid (Table II). At the end of the experiment ( 7 weeks), 40 live bees were sampled from each group, killed on dry ice, and stored at $-80{ }^{\circ} \mathrm{C}$ for further molecular analysis.

\subsection{Landscape analysis}

In order to test the presence or absence of pesticide residues that forager bees may have encountered in the major available crops, whole flowers of the surrounding crops were sampled for chemical analysis. During the flowering period of each crop (corn, cotton, soybean, and sorghum), flowers from the closest four to six major crop fields surrounding each location were randomly sampled at 15-20 spots per field (Table III). Flower samples of each crop type and location were pooled and stored at $-80^{\circ} \mathrm{C}$ for chemical analysis. Honey bee and vegetation samples were shipped on dry ice for pesticide residue detection.

\subsection{Visited crops and flowers}

Marked foragers of each location are expected to forage in the surrounding crop fields and gather pollen and nectar from the available sources. Nevertheless, in order to precisely determine the visited crops and flowers without perturbing the experimental hives with pollen traps, pollen were trapped at eight time points from neighbor hives in each apiary and were subsequently identified.

\subsection{Gene expression}

Total RNA was extracted from the recovered foragers' brain using TRIzol ${ }^{\circledR}$ Reagent protocol from Invitrogen (Chomczynski 1993) with some modifications. Brains of 20 or 10 foragers that were randomly selected from each sample were removed from dry ice, rapidly dissected, and immediately added separately to $1 \mathrm{~mL}$ TRIzol with $5 \mathrm{mg}$ of acid-washed glass beads and gently mixed for $2 \mathrm{~min}$. Two hundred microliters of chloroform was added, and the total mixture was incubated at room temperature for $15 \mathrm{~min}$ followed by a centrifugation at $10,200 \mathrm{rpm}$ for $15 \mathrm{~min}$ at $4{ }^{\circ} \mathrm{C}$.

Three hundred microliters of the supernatant was transferred to a fresh tube, and the tube was washed with $500 \mu \mathrm{L}$ each of isopropanol and incubated for $15 \mathrm{~min}$ at room temperature, followed by centrifugation at $10,200 \mathrm{rpm}$ for $15 \mathrm{~min}$ at $4{ }^{\circ} \mathrm{C}$. The pellet was subsequently washed with $1 \mathrm{~mL} \mathrm{75 \%}$ ethanol and centrifuged at 10,200 rpm for $15 \mathrm{~min}$ at $4{ }^{\circ} \mathrm{C}$. Finally, the RNA pellet was well dried and $60 \mu \mathrm{L}$ of nuclease-free water was added. RNA extractions were nanodropped (Thermo Scientific NanoDrop 2000/2000c Spectrophotometers) for RNA quantity and quality and were diluted to $200 \mathrm{ng} / \mu \mathrm{L}$ and stored at $-80{ }^{\circ} \mathrm{C}$.

Two-step reverse transcription quantitative PCR (RT-qPCR) was used to quantify the genetic expression of five different genes in the bee brains. One microgram of RNA was used as a template for cDNA synthesis using BioBasic High Reverse Transcriptase kits and random hexamer primers. RT-qPCR was performed, in triplicate, on a BioRad CFX384 using LifeTechnologies PowerUP SYBR Green master mix. The studied genes were as follows: (1) acetylcholinesterase (AChE), (2) catalase (CAT), (3) glutathione-S-transferase D1 (GstD1), (4) glutathione-S-transferase S3 (GstS3), and (5) glutathione-S-transferase S4 (GstS4) (Corona and Robinson 2006; Williamson et al. 2013; Alburaki et al. 
Table I. Timetable and results of the main experimental procedures of the field study, showing the introduction and collection dates of the marked honey bees

\begin{tabular}{|c|c|c|c|c|c|c|c|c|}
\hline $\begin{array}{l}\text { Location } \\
\text { Parameter }\end{array}$ & $\begin{array}{l}\text { Introduction } \\
\text { date } 2015\end{array}$ & $\begin{array}{c}\text { No. of } \\
\text { marked } \\
\text { bees }\end{array}$ & $\begin{array}{l}\text { Age of } \\
\text { marked } \\
\text { bees } \\
\text { (day) }\end{array}$ & $\begin{array}{l}\text { Marking } \\
\text { color }\end{array}$ & $\begin{array}{l}\text { Collection } \\
\text { date } 2015\end{array}$ & $\begin{array}{c}\text { Time } \\
\text { marked- } \\
\text { bees left } \\
\text { in hive } \\
\text { (day) }\end{array}$ & $\begin{array}{l}\text { No. of } \\
\text { recovered } \\
\text { foragers }\end{array}$ & $\begin{array}{l}\text { Percent- } \\
\text { age of } \\
\text { forager } \\
\text { mortality }\end{array}$ \\
\hline \multirow[t]{4}{*}{ Jackson } & 12 June & 300 & 1 & White & 24 July & 42 & 0 & 100 \\
\hline & 29 July & 300 & 1 & Red & 18 August & 21 & 205 & 31.7 \\
\hline & 18 August & 300 & 1 & Yellow & 9 September & 22 & 175 & 41.7 \\
\hline & $\begin{array}{l}16 \\
\text { September }\end{array}$ & 300 & 1 & White & 6 October & 20 & 53 & 82.4 \\
\hline Total & & & & & & & $433 / 1200$ & \\
\hline \multirow[t]{4}{*}{ Milan } & 12 June & 300 & 1 & White & 24 July & 42 & 0 & 100 \\
\hline & 29 July & 300 & 1 & Red & 18 August & 21 & 204 & 32 \\
\hline & 18 August & 300 & 1 & Yellow & 9 September & 22 & 119 & 60.4 \\
\hline & $\begin{array}{l}16 \\
\text { September }\end{array}$ & 300 & 1 & White & 6 October & 20 & 255 & 15 \\
\hline Total & & & & & & & $578 / 1200$ & \\
\hline \multirow[t]{4}{*}{ Yum-Yum } & 12 June & 300 & 1 & White & 24 July & 42 & 0 & 100 \\
\hline & 29 July & 300 & 1 & Red & 18 August & 21 & 184 & 38.7 \\
\hline & 18 August & 300 & 1 & Yellow & 9 September & 22 & 104 & 68.8 \\
\hline & $\begin{array}{l}16 \\
\text { September }\end{array}$ & 300 & 1 & White & 6 October & 20 & 230 & 23.4 \\
\hline Total & & & & & & & $518 / 1200$ & \\
\hline \multirow{4}{*}{$\begin{array}{l}\text { Chicka- } \\
\text { saw }\end{array}$} & 12 June & 300 & 1 & White & 24 July & 42 & 16 & 94.7 \\
\hline & 29 July & 300 & 1 & Red & 18 August & 21 & 185 & 38.4 \\
\hline & 18 August & 300 & 1 & Yellow & 9 September & 22 & 81 & 73 \\
\hline & $\begin{array}{l}16 \\
\text { September }\end{array}$ & 300 & 1 & White & 6 October & 20 & 275 & 8.4 \\
\hline Total & & & & & & & $557 / 1200$ & \\
\hline
\end{tabular}

Number of marked and recovered foragers per date and location as well as percentages of forager mortality in each location

2015). Primers were designed based on the full sequences of these genes available from the NCBI database under accession numbers: (1) AB181702.1, (2) NM001178069.1, (3) NM001178028.1, (4) XM006572044.1, and (5) NM001142656.2. The studied genes were normalized using GeNorm (Vandesompele et al. 2002) in all the RT-qPCR runs using a set of five reference genes (28S, Actin, CamIlk, GAPDH, and E2F) known to be accurate and stable in honey bee tissues (Scharlaken et al. 2008). Primers' sequences of both reference and studied genes are available in the "Data accessibility" section.

\subsection{Detection of pesticide residues}

Pesticide residues were quantified in the recovered foragers as well as in the flowers of the corn, cotton, soybean, and sorghum using liquid chromatographymass spectrometry (LC-MS) (Barnett et al. 2007; Walorczyk and Gnusowski 2009). All the chemical analyses for pesticide residue detection were processed at the USDA National Scientific Laboratories in Gastonia, NC. A comprehensive chemical analysis that included 174 chemical active substances was run for each sample, and positive results were reported in the text. 
Table II. Laboratory feeding procedures conducted on the four caged honey bee groups (three treatments and one control)

\begin{tabular}{lllll}
\hline & Group A & Group B & Group C & Group D \\
\hline No. of bee/cage & 100 & 100 & 100 & 100 \\
Age of bee & 1-day-old & 1-day-old & 1-day-old & 1-day-old \\
Product fed & Sugar syrup & Sugar syrup & Sugar syrup & Sugar syrup \\
& Protein patty & Protein patty & Protein patty & Protein patty \\
& Water & Water & Water & Water \\
Pesticide & None & Neonicotinoids & Neonicotinoids & Neonicotinoids \\
Molecule & None & Imidacloprid & Imidacloprid & Imidacloprid \\
Category & Control & Treatment & Treatment & Treatment \\
Imidacloprid in sugar syrup PPB & 0 & 5 & 20 & 100 \\
Experiment duration (week) & 7 & 7 & 7 & 7 \\
No. of bee analyzed & 40 & 40 & 40 & 40 \\
No. of brain/RNA extraction & 10 & 10 & 10 & 10 \\
No. of biological replicate (RNA) & 4 & 4 & 4 & 4 \\
Gene studied & & AChE, CAT, GstD1, GstS3, GstS4 & \\
\hline
\end{tabular}

Group A is the control group in which caged bees were supplied by sugar syrup that contained no chemicals. Groups B, C, and D were fed sugar syrup that contained 5, 20, and 100 PPB imidacloprid concentrations, respectively. Forty bees per group were sampled alive at the end of the experiment and analyzed for gene expression

Complete analytical reports can be found in the DOI in the "Data accessibility" section.

\subsection{Statistical analysis}

Statistical analyses and figure generation were carried out and generated in the $\mathrm{R}$ environment ( $\mathrm{R}$ Core Team 2011). Variables of this study included (1) number of recovered foragers (forager mortality); (2) AChE, CAT, GstD1, GstS3, and GstS4 expression; and (3) percentage of $A G$ in the total foraging area. Data were treated either per location (four groups) to study the landscape effects on honey bee foragers or per AG area (two groups) to explore the putative impacts of the exposure to pesticides on the honey bee colonies. Variables were first tested for normality using the ShapiroWilk test and were normalized using a log transformation. When a simple comparison of two variables was needed, the Welsh two-sample $t$ test was used at a 95\% confidence interval. Analysis of variance (ANOVA) was also performed to quantify the difference between variables regarding the treatment and time at a $95 \%$ confidence level. Principal component analyses (PCAs) were carried out using "Devtools" Package as well as "FactoMine" to calculate the percentage of the variability expressed in three-dimensional space. Correlations between genetic expressions of the studied genes for both caged bees and field-recovered foragers were performed using the $\mathrm{R}$ libraries "Performance Analytics" and "Corrplot."

\section{RESULTS}

\subsection{Landscape study}

The locations and their agricultural classification based on the GIS were as follows: Jackson (low AG area with urban activity), Milan (high AG area), Yum-Yum (very high AG area), and Chickasaw (a natural park that contains no agricultural activity; non-AG area) (Figure 1, Table III). Within a 2.5-km-radius foraging distance, honey bees had access to each location (Jackson, Milan, YumYum, and Chickasaw) to 19, 55, 71, and 5\% agricultural area or crop fields, respectively (Figure 1). The remaining landscapes consisted of forest, woodland, open water, and urban areas (such as 
Table III. Background, location, and distribution of the experimental colonies

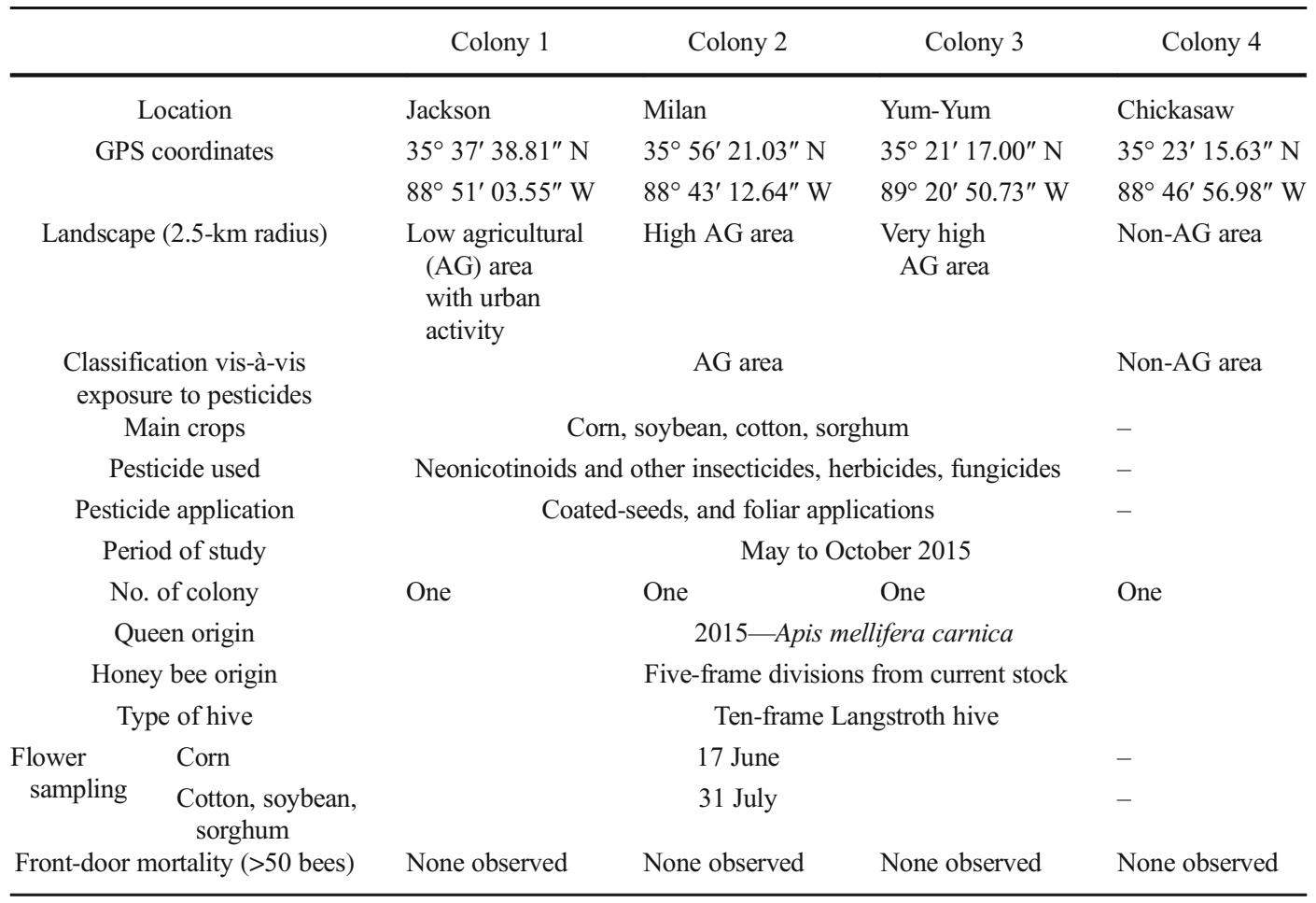

GIS landscape classification of each colony location in a $2.5-\mathrm{km}$ radius. Main crops and pesticides used in the studied locations as well as sampling dates from each location

- not applicable or not seen during in-field scout and/or study

buildings and roads). Therefore, the highest AG area was located in Yum-Yum (71\%), followed by Milan (55\%). The Jackson location was a relatively low AG area (19\%) but had a substantial urban component (46\%). Chickasaw was considered the control treatment of this study with only $5 \%$ AG area. In some cases, and in order to evaluate the total exposure to pesticides, results were exposed by two landscape groups: AG and non-AG groups.

\subsection{Recovered foragers}

Recovered forager and/or bees varied among dates and locations (Table II). On the first collection date (24 July), when marked bees were left for 42 days in their respective hives, no marked bees were recovered except for the Chickasaw location where only 16 bees were recovered (Table I, Figure 2). The highest number of recovered bees was observed in Chickasaw on the last date (16
September), in which 275 of 300 bees (91.6\%) were recovered (Table I). No significant differences were observed in the total recovered bees whether per locations (Jackson, Milan, Yum-Yum, Chickasaw) or per treatment (AG area and non-AG area) (Figure 2). However, regardless the treatment factor, there was a large difference in the number of recovered bees among dates $(P<0.001)$.

\subsection{Gene expression}

Different gene expression patterns were identified in recovered foragers' brains from each location for each studied gene (Figure 3). No significant differences were recorded for the first three genes $(\mathrm{AChE}$, CAT, GstD1) among bees of the studied locations or between the studied locations and control bees (CT). However, the expression of both GstS3 and GstS4 were significantly higher $(P<0.05)$ between $\mathrm{CT}$ and both $\mathrm{C}$ and $\mathrm{M}$ for GstS3 as well as between $\mathrm{CT}$ 


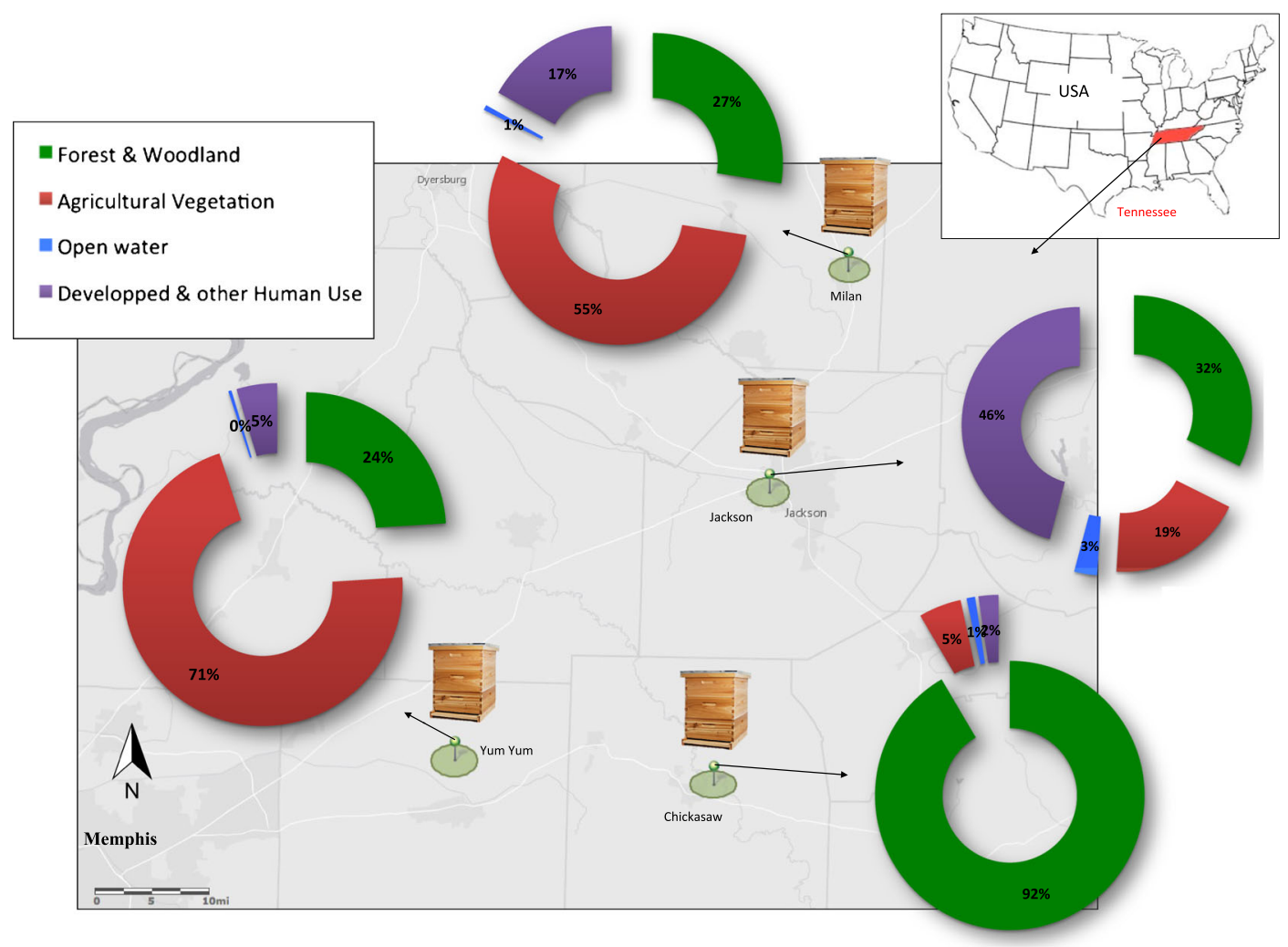

Figure 1. Geographical location of the four studied colonies and locations in western Tennessee, USA. The GIS study to determine the landscape nature at each location was conducted on a $2.5-\mathrm{km}$ radius. The landscape classifications included Jackson (low AG area with human use, 19\%), Milan (high AG area, 55\%), Yum-Yum (very high AG area, $71 \%$ ), and Chickasaw (non-AG area, 5\%). One honey bee colony was placed in each location.

and all locations $(\mathrm{C}, \mathrm{J}, \mathrm{M}$, and $\mathrm{Y})(P<0.001)$ for GstS4. AChE expression negatively correlated with both CAT $(r=-0.84)$ and GstS4 $(r=-0.88)$ and positively with GstS3 ( $r=0.94$ ) (Figure 3). For bees fed in the lab with sugar water tainted with imidacloprid, none of the five genes showed significant differences among the four groups of bees (A, $\mathrm{B}, \mathrm{C}$, and D), except for GstD1 $(P<0.05)$ with no paired-groups significance (Figure 4$)$. Principal component analyses showed differences among recovered foragers from the four locations on axes 1 and 2 (Figure 5) with respect to the five studied genes. The variability expressed on both axes 1 and 2 were 45.95 and $30.60 \%$, respectively (Figure 5). Samples from Milan and Jackson showed more resemblance to each other than to bees from the other locations (Chickasaw and Yum-Yum) with respect to the gene expression of the five studied genes.

\subsection{Pesticide residues}

Recovered foragers The results of the recovered foragers showed some residues of different pesticides (Table IV). On the first collected date, neonicotinoids were only identified on foragers at the Jackson location ( $1 \mathrm{ng} / \mathrm{g}$ imidacloprid). Milan's foragers contained $10.6 \mathrm{ng} / \mathrm{g}$ azoxytrobin, a fungicide, on the same collected date. Cyhalothrin (5.4 ng/g), a synthetic pyrethroid insecticide, was identified on foragers of Yum-Yum on the second date (9 September). No pesticides were detected in Chickasaw foragers (non-AG area) at any time or any forager on the third sampling date (October 6) (Table IV).

Crop flowers Various pesticide residues were found at different concentration in crop flowers collected from crop fields surrounding our apiaries. High 

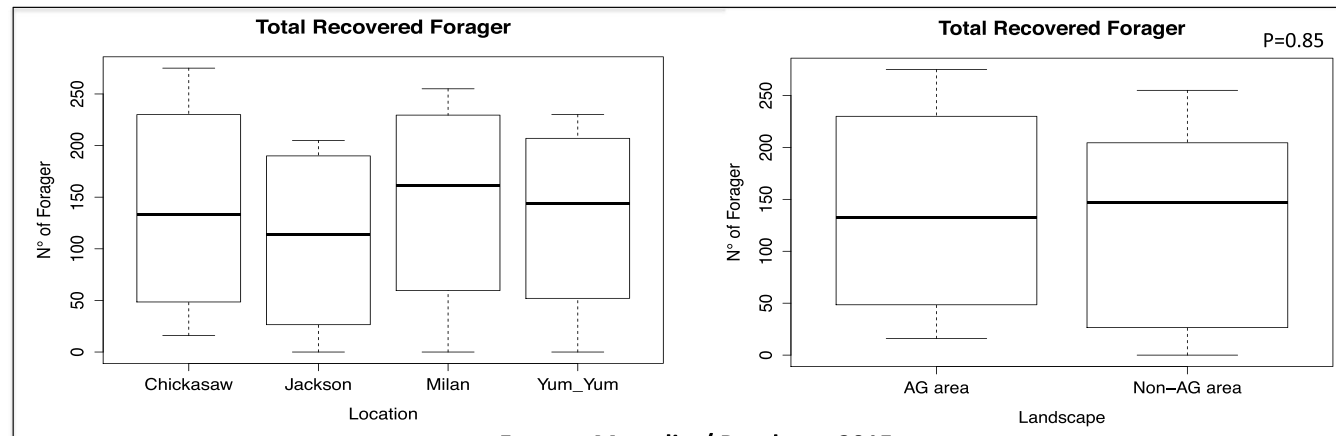

Forager Mortality/ Per date - 2015

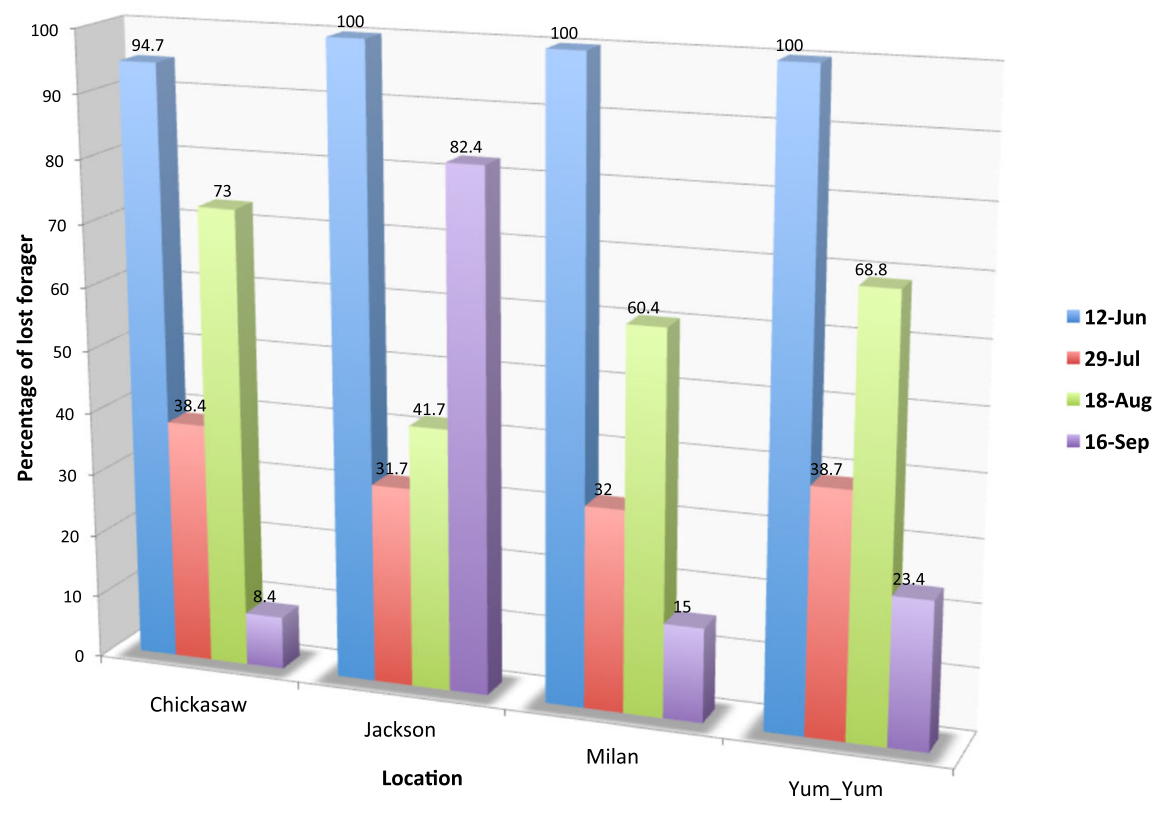

Figure 2. Percentage of the recovered honey bee foragers per date from each location (Jackson, Milan, Yum-Yum, and Chickasaw) as well as the total number of overtime-recovered foragers per location and landscape (AG and nonAG areas).

concentrations of neonicotinoids were recorded on cotton flowers at both the Milan and Yum-Yum locations at $25.3 \mathrm{ng} / \mathrm{g}$ (imidacloprid) and $23.7 \mathrm{ng} / \mathrm{g}$ (thiamethoxam), respectively (Table IV). Significant concentrations of acephate on cotton were detected in Jackson (309 ng/g) and Milan (4190 ng/g) as well as other insecticides such as bifenthrin and methamidophos (Table IV). Concentrations of imidacloprid (5.3 and $2.4 \mathrm{ng} / \mathrm{g}$ ) were also recorded on the soybean flowers of Jackson and Yum-Yum, respectively. On sorghum, various concentrations of cyhalothrin, bifenthrin, and spinosad (all insecticides) were identified at the Jackson and Milan locations. Other pesticides detected at low concentrations are detailed in Table IV. Identification of the trapped pollen collected at eight different time points from hives neighboring our experimental colonies clearly evidenced that foragers intensively visited and collected soybean, sorghum, and corn pollen (data not shown).

\section{DISCUSSION}

This study examined how agricultural pesticides used extensively in southern US field crops may 

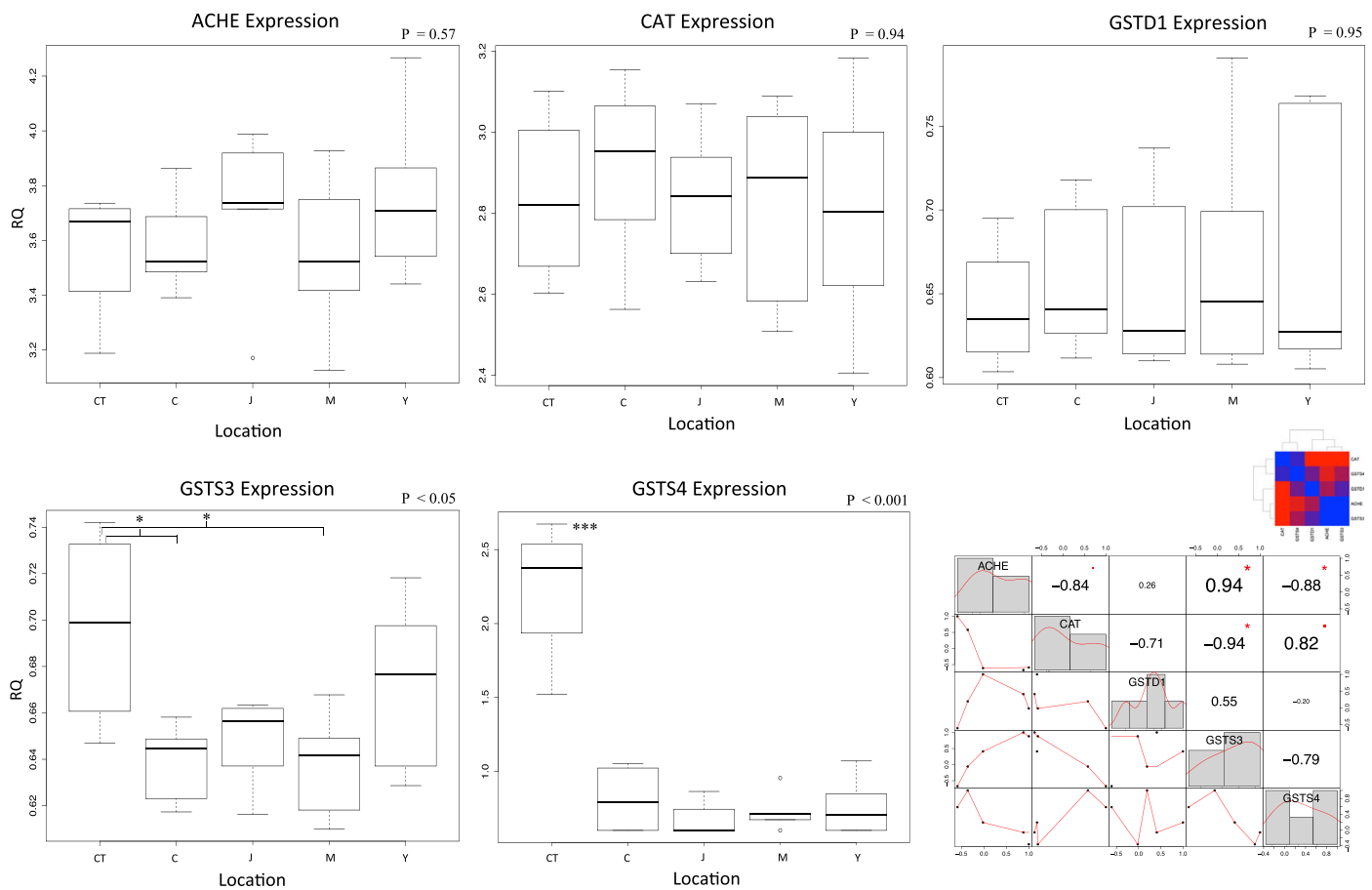

Figure 3. Gene expression results of the five studied genes (AChE, CAT, GstD1, GstS3, and GstS4) performed by RT-qPCR on the recovered forgers' brains. Codes of $X$-axis are as follows: "C," Chickasaw; "CT," control; "J," Jackson; "M," Milan; and "Y," Yum-Yum. $P$ values are $* P<0.05, * * * P<0.001$ and are calculated based on ANOVA for overtime expression at a $95 \%$ confidential level. The correlation matrix with the correlation coefficient values of the five studied genes are also provided.

contribute to in-field forager mortality of honey bees. The activities of the AChE, a neural enzyme, along with three other detoxification enzymes (GstD1, GstS3, and GstS4) and the CAT, were studied in bee brains in order to characterize physiological stresses resulting from exposure to pesticides. The four experimental locations (Jackson, Milan, Yum-Yum, and Chickasaw) were carefully chosen based on landscape structures and potential exposure to pesticides. As organic crop production is rare in western Tennessee, a non-cropping location (Chickasaw) was placed in a non-AG area in a Tennessee state park where little or no agriculture occurred within bee foraging distance.

On the first collection date (24 July), when bees were left in-hive for 42 days, only 16 marked foragers were recovered from Chickasaw and none were recovered from the other locations. In order to increase the number of the recovered foragers from all locations, we shortened the period between introduction and collection of bees to 20-22 days (Table I). Although the number of foragers that were recovered varied among locations, no significant differences were observed among locations or between treatment categories (AG and non-AG areas) (Figure 2). This indicates that foraging in AG or non-AG fields did not have significant impact on in-field forager mortality. This conclusion is encouraging to beekeepers but might not be valid under all environmental conditions. Nonetheless, the concentration of some insecticides found on the flowers of the measured crops indicate that foraging honey bees could be exposed to high concentrations of those pesticides (Table IV). For instance, concentrations of imidacloprid and thiamethoxam (25.3 and $23.7 \mathrm{ng} / \mathrm{g}$ ) that theoretically exceed the bee oral $\mathrm{LD}_{50}$ were identified in cotton flowers of Milan and Yum-Yum locations, respectively, whereas no neonicotinoids were detected in Jackson's cotton flowers (Table IV). Acephate was also recorded at elevated concentrations in the cotton flowers of 

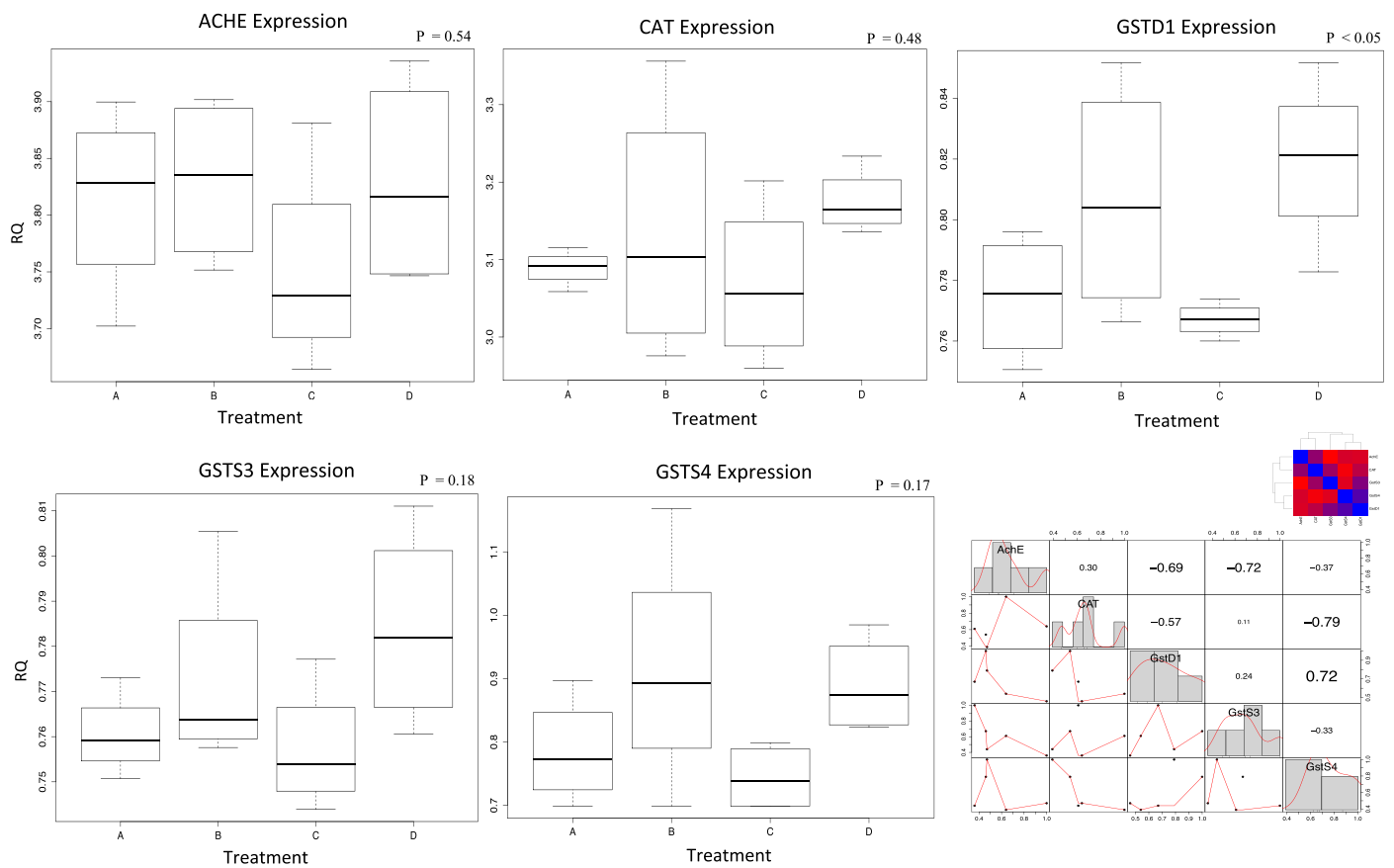

Figure 4. Gene expression results of the five studied genes (AChE, CAT, GstD1, GstS3, and GstS4) performed by RT-qPCR on honey bee brains fed in the lab with different imidacloprid concentrations. A, B, C, and D are the four studied groups detailed in Table III. ANOVA shows no significant differences among the studied groups for any of the studied gene except for GstD1 $(P<0.05)$. The correlation matrix shows no significant correlation among the studied genes.

Jackson (309 ng/g) and extremely high concentrations $(4190 \mathrm{ng} / \mathrm{g})$ in Yum-Yum. Other various concentrations of insecticides were detected in the cotton and sorghum flowers of the three AG locations. Low concentrations of imidacloprid were reported on soybean flowers of both Jackson and Yum-Yum locations, while no neonicotinoids were found in corn and sorghum flowers (Table IV). The neonicotinoid residues in our study are much higher than what has been reported in a recent study conducted in western Tennessee (Stewart et al. 2014), but this study was targeting seed treatment effects whereas our current study would be influenced by foliar-applied insecticides. The recovered foragers seemed not to have encountered the pesticides detected in the crops' flowers, as no high concentrations were detected in those bees (Table IV). The absence of significant pesticide residues in the recovered foragers likely explains the similarity in foragers' mortality between AG and non-AG areas, as no link was established between the foragers and the elevated concentrations of pesticides found in the crop flowers (Figure 2).

For recovered foragers, none of the antioxidant genes showed significant differences among the locations, which suggests that the foraging environment (as quantified as percentage AG area) is not involved in enhancing honey bee physiological stress or the detoxification process. Interestingly, expression of both the GstS3 and GstS4 genes were higher in control bees that were killed at 1-day-old (Figure 3). This finding leads to conclude that the expression of the GST genes are most probably related to the bee age, as described in (Słowińska et al. 2015), rather than exposure to pesticides (Figure 3).

In order to assess any interference that might have biased the gene expressions of the recovered foragers (e.g., environmental conditions), we tested these genes on bees fed with imidacloprid in the lab. Surprisingly, none of those genes including the AChE significantly differed from the control group (A) that was not fed with imidacloprid 

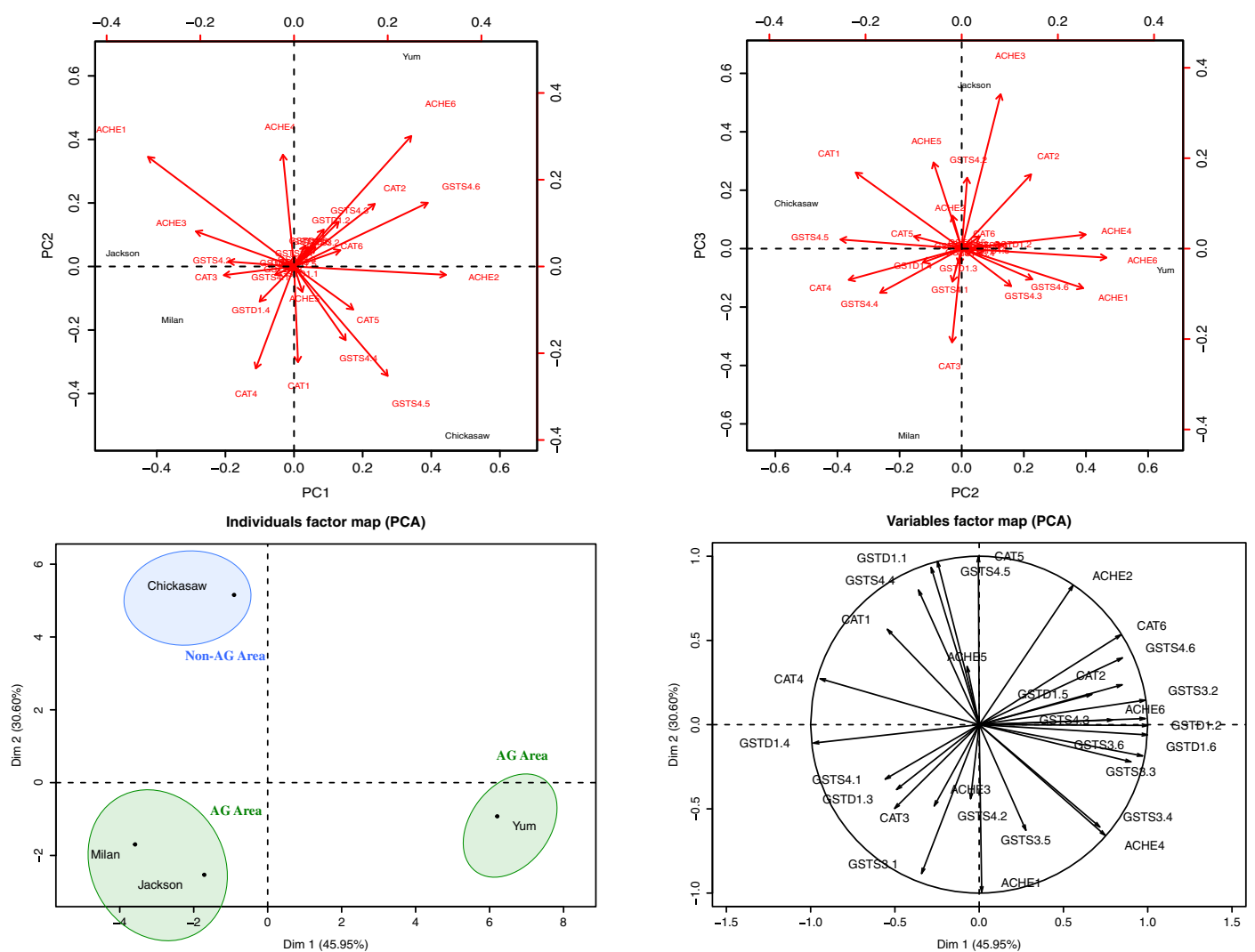

Figure 5. Principal component analysis (PCA) of the five studied genes of the recovered foragers expressed on axes 1,2 , and 3. Individuals and variable factor maps are provided along with the variable percentages expressed on the first two axes. Differentiation of three distinct groups (AG and non-AG areas) is clarified with eclipses on the PCA individual factor map. Axes 1 and 2, respectively, absorbed $46.0 \%$ and $30.6 \%$ of the dataset variability.

(Figure 4 and Table II). On the one hand, the genes of the GST family are known to be upregulated in response to abiotic stresses, such as cold, heat, and insecticides (Yan et al. 2013). On the other hand, AChE response to imidacloprid concentrations are similar to what has been found by Badiou-Bénéteau et al. (2012), in which bees fed in the lab with thiamethoxam lethal doses showed no AChE response, although the same authors suggested that AChE expression could be considered a robust biomarker for other insecticide exposure in living bees (Badiou et al. 2008). Previous field and laboratory studies investigating the neonicotinoid impact on honey bee survival (more precisely on the AChE activity) reported elevated levels of AChE activity in honey bee brains when subjected to thiamethoxam or clothianidin (Boily et al. 2013; Alburaki et al. 2015). Our contradictory results regarding the relationship between AChE activity and exposure to pesticides suggest a complex physiological response of honey bees to abiotic stressors. Thus, beside the level of expression, some other key factors such as the slope of the response and the short-term and longterm response magnitudes to stressors, should be considered to accurately quantify gene expression (Chechik and Koller 2009).

The overall expression of the five studied genes on the recovered foragers showed an interesting separation of the three groups of locations (Figure 5). The highest similarity in gene response was found to be between foragers of the Milan and Jackson locations. Chickasaw foragers (nonAG area), however, are clearly well separated from both other groups as well as Yum-Yum foragers (AG area) (Figure 5). It is hard to conclude 


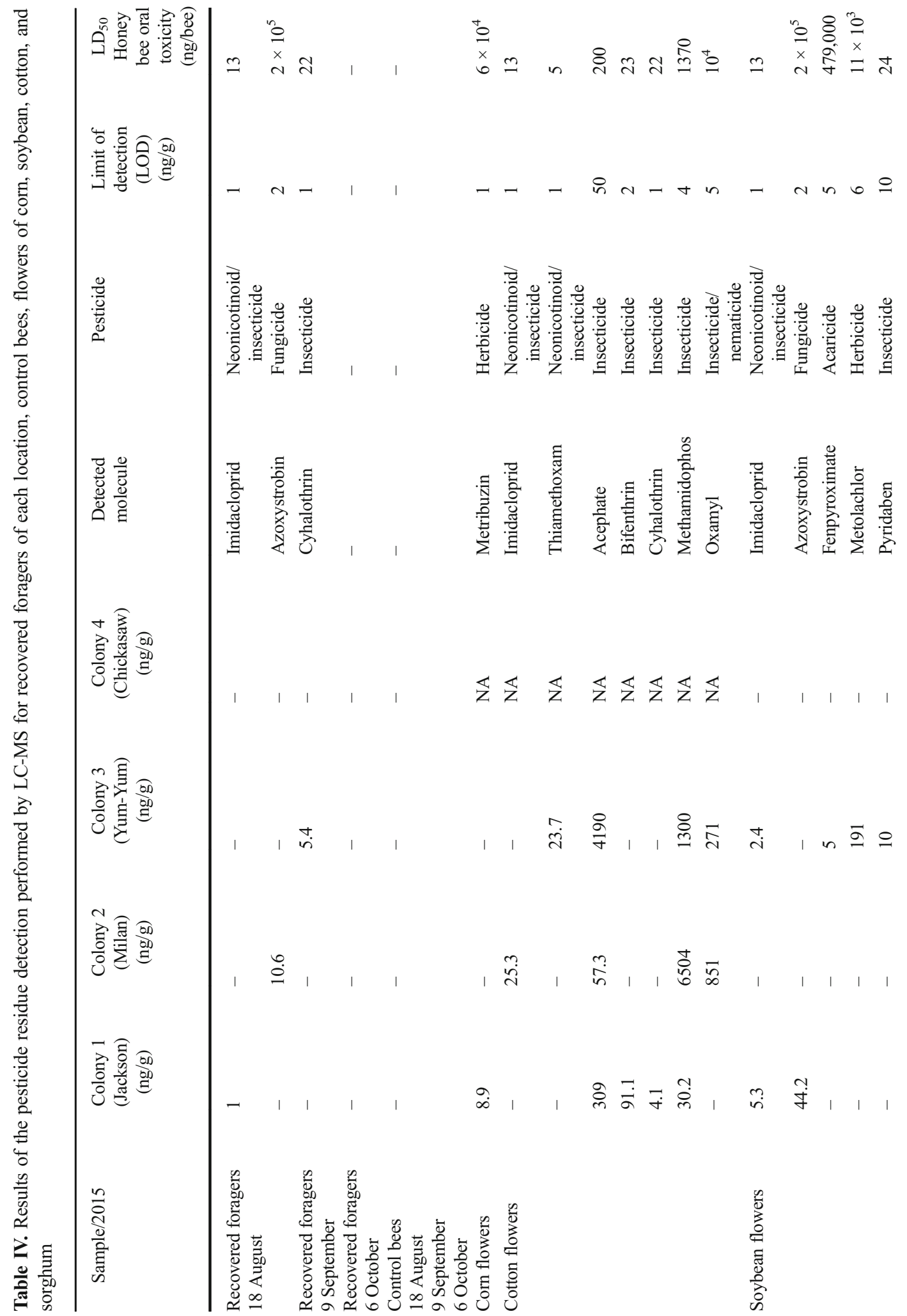




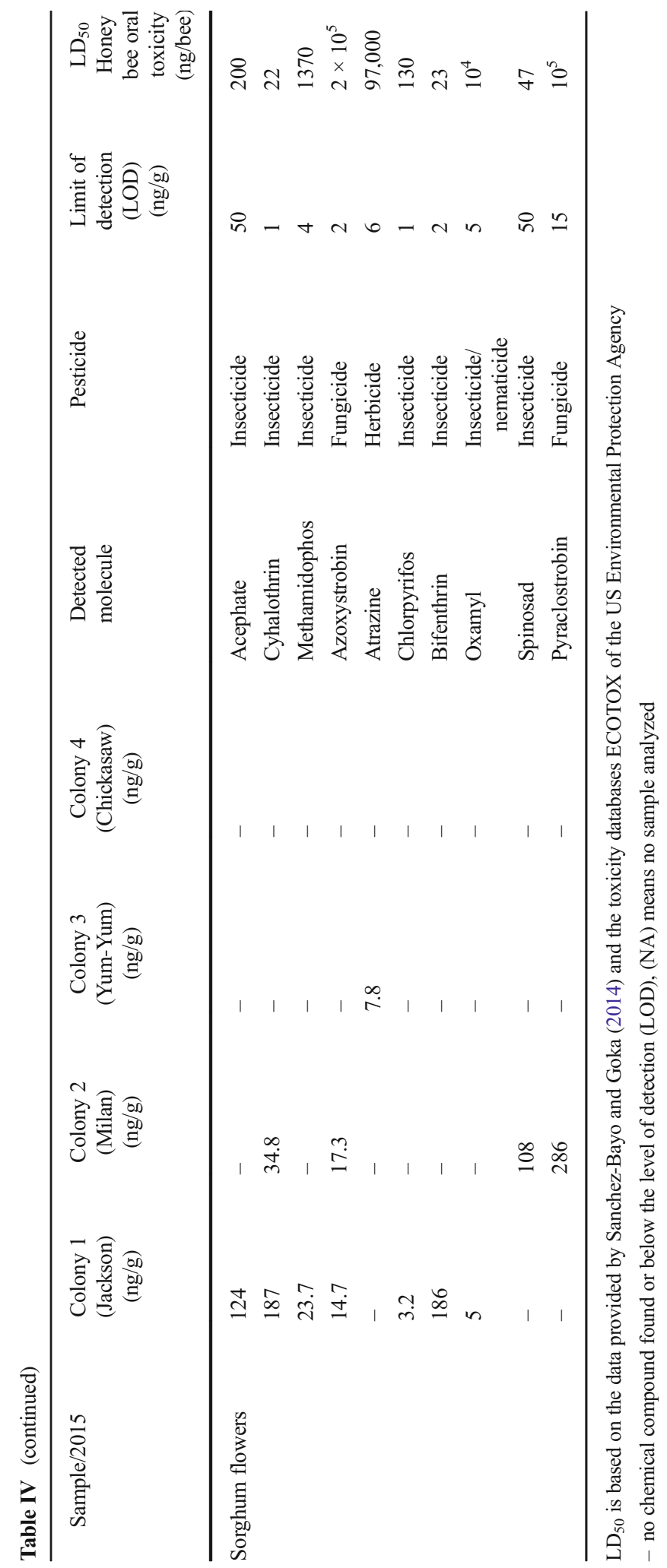


at this point that these differences were a result of different treatment factors, especially because low pesticide levels were detected in recovered foragers (Table IV and Figure 5). Our analyses suggest that a wise option would be to select candidate groups of genes that exhibit similar response to particular molecules in order to find more appropriate honey bee biomarkers for exposure to pesticides.

\section{ACKNOWLEDGMENTS}

We are grateful to the Chickasaw Park Administration and the UT Research and Education Center at Milan to have kindly hosted our experimental hives during this study in both locations at Milan and Chickasaw State Park. We are also grateful to farmers in YumYum to have provided a space for our hives in this location as well. We also thank the "USDA, ARS Areawide Pest Management Program" for partial funding support. This study was supported by a grant from the University of Tennessee and the USDA number R124610336.

Authors' contribution MA, SDS, DRT, and JA conceived and designed the experiment; JAS, GL, and WGM participated in the experimental design and provided material support. MA, DC, EM, and HK carried out the molecular analyses. MA, SJS, and SDS performed the experiment and collected the data. WGM and MW performed the laboratory honeybee feeding part. MA, DRT and SDS analyzed and interpreted the data. All authors discussed the data and approved the results of this study.

\section{COMPLIANCE WITH ETHICAL STANDARDS}

Conflict of interest The authors declare that they have no conflict of interest.

Data accessibility Relevant data and supporting materials for this study (e.g., full list of detected chemical, RT-qPCR primers, locations' coordinates, photos) are made available on the LabArchives' Web site under the DOI: http:// dx.doi.org/10.6070/H4KK98T2

Effets du paysage et des pesticides sur les abeilles: survie des butineuses et expression de l'acétycholinestérase et des gènes oxydatifs du cerveau
Apidae / Apis mellifera / paysage agricole / cultures / expression génique

Auswirkungen von Landschaft und Pestiziden auf Honigbienen: Überleben der Sammlerinnen und Expression von Acetylcholinesterasegenen und oxidativem Stressgenen im Gehirn

\section{Honigbienensammlerinnen / Agrarlandschaften / Nutzpflanzen / Genexpression}

\section{REFERENCES}

Aizen M.A., Garibaldi L.A., Cunningham S.A., Klein A.M. (2009) How much does agriculture depend on pollinators? Lessons from long-term trends in crop production. Ann. Bot. 103 (9): 1579-1588.

Alburaki A. (1990) Etude de l'influence d'une familiarisation précoce à une partie ou un extrait de plante mellifère sur les comportements de récolte de l'abeille domestique (Apis mellifera mellifera L.) amélioration qualitative et quantitative de la prodution de miel par la ruche. Atelier national de reproduction des thèses, Lille, France

Alburaki M., Boutin S., Mercier P.L., Loublier Y., Chagnon M., et al. (2015) Neonicotinoid-coated Zea mays seeds indirectly affect honeybee performance and pathogen susceptibility in field trials. PloS one, 10 (5)

Aliouane Y., El Hassani A.K., Gary V., Armengaud C., Lambin M., et al. (2009) Subchronic exposure of honeybees to sublethal doses of pesticides: effects on behavior. Environ. Toxicol. Chem. 28(1): 113-122.

Bacandritsos N., Granato A., Budge G., Papanastasiou I., Roinioti E., et al. (2010) Sudden deaths and colony population decline in Greek honey bee colonies. J. Invertebr. Pathol. 105 (3): 335-340.

Badiou A., Meled M., Belzunces L.P. (2008) Honeybee Apis mellifera acetylcholinesterase - a biomarker to detect deltamethrin exposure. Ecotoxicol. Environ. Saf. 69 (2): 246-253.

Badiou-Bénéteau A., Carvalho S.M., Brunet J.L., Carvalho G.A., Bulete A., et al. (2012) Development of biomarkers of exposure to xenobiotics in the honey bee Apis mellifera: application to the systemic insecticide thiamethoxam. Ecotoxicol. Environ. Saf. 82 : 22-31.

Barnett A.E., Charlton J.A., Fletcher R.M. (2007) Incidents of bee poisoning with pesticides in the United Kingdom, 1994-2003. Pest Manag. Sci. 63 : 1051-1057.

Blacquière T., Smagghe G., van Gestel C.A., Mommaerts V. (2012) Neonicotinoids in bees: a review on concentrations, side-effects and risk assessment. Ecotoxicology 21 (4): 973-992.

Boily M., Sarrasin B., Deblois C., Aras P., Chagnon M. (2013) Acetylcholinesterase in honey bees (Apis mellifera) exposed to neonicotinoids, atrazine and glyphosate: laboratory and field experiments. Environ. Sci. Pollut. Res. Int. 20 (8): 5603-5614. 
Chakrabarti P., Rana S., Sarkar S., Smith B., Basu P. (2015) Pesticide-induced oxidative stress in laboratory and field populations of native honey bees along intensive agricultural landscapes in two Eastern Indian states. Apidologie 46 (1): 107-129.

Chechik G., Koller D. (2009) Timing of gene expression responses to environmental changes. J. Comput. Biol. 16 (2): 279-290.

Chomczynski P. (1993) A reagent for the single-step simultaneous isolation of RNA, DNA and proteins from cell and tissue samples. Biotechniques 15(3): 532-534.

Corona M., Robinson G.E. (2006) Genes of the antioxidant system of the honey bee: annotation and phylogeny. Insect Mol. Biol. 15(5): 687-701.

Dainat B., Evans J.D., Chen Y.P., Gauthier L., Neumann P. (2012) Dead or alive: deformed wing virus and Varroa destructor reduce the life span of winter honeybees. Appl. Environ. Microbiol. 78(4): 981-987.

Decourtye A., Devillers J., Genecque E., Menach K.L., Budzinski H., et al. (2005) Comparative sublethal toxicity of nine pesticides on olfactory learning performances of the honeybee Apis mellifera. Arch. Environ. Contam. Toxicol. 48 (2): 242-250.

Durou C., Smith B.D., Romeo M., Rainbow P.S., Mouneyrac C., et al. (2007) From biomarkers to population responses in Nereis diversicolor: assessment of stress in estuarine ecosystems. Ecotoxicol. Environ. Saf. 66 (3): 402-411.

Fischer J., Muller T., Spatz A.K., Greggers U., Grünewald B., et al. (2014) Neonicotinoids interfere with specific components of navigation in honeybees. PloS one 9 (3): e91364.

Fries I. (2010) Nosema ceranae in European honey bees (Apis mellifera). J. Invertebr. Pathol. 103 : S73-S79.

Godfray H.C.J., Blacquière T., Field L.M., Hails R.S., Petrokofsky G., et al. (2014) A restatement of the natural science evidence base concerning neonicotinoid insecticides and insect pollinators. Proc. R. Soc. B: Biol. Sci. 281(1786)

Henry, M., Cerrutti, N., Aupinel, P., Decourtye, A., Gayrard, M., et al. (2015) Reconciling laboratory and field assessments of neonicotinoid toxicity to honeybees. Proc. Biol. Sci. 282(1819)

Jeschke P., Nauen R., Schindler M., Elbert A. (2011) Overview of the status and global strategy for neonicotinoids. J. Agric. Food Chem. 59 (7): 2897-2908.

Johnson R.M., Ellis M.D., Mullin C.A., Frazier M. (2010) Pesticides and honey bee toxicity - USA. Apidologie 41 (3): 312-331.

Kremen C., Ricketts T. (2000) Global perspectives on pollination disruptions. Conserv. Biol. 14 : 1226-1228.

Lambert O., Piroux M., Puyo S., Thorin C., L'Hostis M., et al. (2013) Widespread occurrence of chemical residues in beehive matrices from apiaries located in different landscapes of Western France. PloS one 8(6): e67007.

Lionetto M.G., Caricato R., Giordano M.E., Pascariello M.F., Marinosci L., et al. (2003) Integrated use of biomarkers (acetylcholinesterase and antioxidant enzymes activities) in Mytilus galloprovincialis and
Mullus barbatus in an Italian coastal marine area. Mar. Pollut. Bull. 46 (3): 324-330.

Mackenzie K.E., Winston M.L. (1989) Effects of sublethal exposure to diazinon on longevity and temporal division of labor in the honey bee (Hymenoptera, Apidae). J. Econ. Entomol. 82 (1): 75-82.

Morse R.A., Calderone N.W. (2000) The value of honey bees as pollinators of U.S. crops in 2000. Cornell Univ., Ithaca, New York.

Potts S.G., Biesmeijer J.C., Kremen C., Neumann P., Schweiger O., et al. (2010) Global pollinator declines: trends, impacts and drivers. Trends Ecol. Evol. 25 (6): 345-353.

R Core Team. (2011) R: a language and environment for statistical computing. R Foundation for Statistical Computing, Vienna, Austria.

Samson-Robert O., Labrie G., Mercier P.L., Chagnon M., Derome N., et al. (2015) Increased acetylcholinesterase expression in bumble bees during neonicotinoidcoated corn sowing. Sci. Rep. 5: 12636.

Sanchez-Bayo F., Goka K. (2014) Pesticide residues and bees - a risk assessment. PloS one 9 (4): e94482.

Scharlaken, B., de Graaf, D.C., Goossens, K., Brunain, M., Peelman, L.J., et al. (2008) Reference gene selection for insect expression studies using quantitative realtime PCR: the head of the honeybee, Apis mellifera, after a bacterial challenge. J. Insect Sci. 8

Seeley T.D. (2010) Honeybee democracy. Princeton University Press, Princeton.

Słowińska M., Nynca J., Wilde J., Bąk B., Siuda M., et al. (2015) Total antioxidant capacity of honeybee haemolymph in relation to age and exposure to pesticide, and comparison to antioxidant capacity of seminal plasma. Apidologie 47 (2): 227-236.

Stewart S.D., Lorenz G.M., Catchot A.L., Gore J., Cook D., et al. (2014) Potential exposure of pollinators to neonicotinoid insecticides from the use of insecticide seed treatments in the mid-southern United States. Environ. Sci. \& Technol. 48(16): 9762-9769.

Stoner K.A., Eitzer B.D. (2012) Movement of soil-applied imidacloprid and thiamethoxam into nectar and pollen of squash (Cucurbita pepo ). PloS one 7 (6): e39114.

Van der Sluijs J.P., Simon-Delso N., Goulson D., Maxim L., Bonmatin J.-M., et al. (2013) Neonicotinoids, bee disorders and the sustainability of pollinator services. Curr. Opin. Environ. Sustain. 5 : 293-305.

Vandame R., Meled M., Colin M.E., Belzunces L.P. (1995) Alteration of the homing-flight in the honey-bee Apis mellifera L. exposed to sublethal dose of deltamethrin. Environ. Toxicol. Chem. 14 (5): 855-860.

Vandesompele J., De Preter K., Pattyn F., Poppe B., Van Roy N., et al. (2002) Accurate normalization of realtime quantitative RT-PCR data by geometric averaging of multiple internal control genes. Genome Biol. 3 (7).

VanEngelsdorp D., Speybroeck N., Evans J.D., Nguyen B.K., Mullin C., et al. (2010) Weighing risk factors associated with bee Colony collapse disorder by 
classification and regression tree analysis. J. Econ. Entomol. 103 (5): 1517-1523.

Walorczyk S., Gnusowski B. (2009) Development and validation of a multi-residue method for the determination of pesticides in honeybees using acetonitrilebased extraction and gas chromatography-tandem quadrupole mass spectrometry. J. Chromatogr. A 1216: 6522-6531.

Williamson S.M., Moffat C., Gomersall M., Saranzewa N., Connolly C., et al. (2013) Exposure to acetylcholinesterase inhibitors alters the physiology and motor function of honeybees. Front. Physiol. $4: 13$. doi: 10.3389/ fphys.2013.00013.

Williamson S.M., Willis S.J., Wright G.A. (2014) Exposure to neonicotinoids influences the motor function of adult worker honeybees. Ecotoxicology 23 (8): 1409-1418.
Williamson S.M., Wright G.A. (2013) Exposure to multiple cholinergic pesticides impairs olfactory learning and memory in honeybees. J. Exp. Biol. 216 (10): 17991807.

Withgott J. (1999) Pollination migrates to top of conservation agenda. Bioscience 49: 857-862.

Wu J.Y., Smart M.D., Anelli C.M., Sheppard W.S. (2012) Honey bees (Apis mellifera) reared in brood combs containing high levels of pesticide residues exhibit increased susceptibility to Nosema (Microsporidia) infection. J. Invertebr. Pathol. 109 (3): 326-329.

Yan H., Jia H., Gao H., Guo X., Xu B. (2013) Identification, genomic organization, and oxidative stress response of a sigma class glutathione S-transferase gene (AccGSTS1) in the honey bee, Apis cerana cerana . Cell Stress \& Chaperones 18(4): 415-426. 